\title{
ヒスタミンと抗ヒスタミン薬に関する薬理学研究の新しい展望
}

谷内 一彦

東北大学大学院医学系研究科・機能薬理学

\section{New Perspectives of Pharmacological Research on Histamine and Antihistamines}

Kazuhiko Yanai

Department of Pharmacology, Tohoku University Graduate School of Medicine

ヒスタミンは, 肥満細胞, 胃の ECL 細胞などに存在して, 平滑筋収縮, 血管透過性, 胃酸分泌, 好酸球機能など多くの機能に関係している。またヒスタミンは中枢神経にも存在して覚醒アミンとし て特に重要な役割を果たしている。ヒスタミンには未解明の機能が多く残されており, 特に, 新しく 同定された $\mathrm{H} 4$ 受容体は注目を集めている。ヒスタミンは代表的な痒み惹起物質であるが，最近，新 しい痒み研究が展開されている。(1)熱帯植物 Cowhageによる痒みはヒスタミンと異なり, mechanoresponsive C 線維により伝達され, mechano-insensitive C 線維を介するヒスタミンによる痒みと区 別される。(2)アトピー性皮膚炎患者と正常被験者の fMRI 研究により, ヒト脳内の痒み認知メカニズ ムが異なる。(3)新しい痒み受容分子として GPCRである gastrin-releasing peptide receptor が特異的 に痒みに関倸する受容体として研究が進められている。

抗ヒスタミン薬はイタリアの薬理学者 Daniel Bovetにより1930-40年代に開発され, その後, 多く の中枢神経系作用薬（抗精神病薬や抗うつ薬など）の原型になった。1957年に Bovet はその薬理学的 業績によりノーベル医学生理学賞を受賞している。初期の抗ヒスタミン薬は, アレルギー疾患に対す る効果が認められる一方で, 眠気や口渇, 頻脈といった副作用が問題視されてきた。その後抗ヒス夕 ミン薬の改良が進められ，「非鎮静性」抗ヒスタミン薬が次々と登場している。我々は脳内ヒスタミ ン $\mathrm{H} 1$ 受容体占拠率測定法を開発して，その鎮静作用を 3 段階（非鎮静性，軽度鎮静性，鎮静性）で 評価している。2003年にConsensus Group of New Generation of Antihistamines(CONGA) という国 際的専門家会議が理想的な抗ヒスタミン薬についての基準を明確にしたが，その「非鎮静性」に関し て我々の $\mathrm{H} 1$ 受容体占拠率に基づく分類を採用している。また最近発表された日本皮虐科学会アトピ 一性皮膚炎診療ガイドラインにおいて国内で初めて「非鎮静性」抗ヒス夕ミン薬の基準を明確した が，我々の $\mathrm{H} 1$ 受容体占拠率による分類を取り入れている。国際標準になっている「非鎮静性」抗ヒ スタミン薬の第一選択としての使用を切に打願いしたい。 